DOI 10.37882/2500-3682.2021.09.14

\title{
ФЕНОМЕН ВИРТУАЛЬНОЙ РЕАЛЬНОСТИ В ФИЛОСОФСКОМ ДИСКУРСЕ
}

\section{THE PHENOMENON OF VIRTUAL REALITY IN PHILOSOPHICAL DISCOURSE}

V. Skopa

Summary: The phenomenon of virtual reality is considered in a historical retrospective through the prism of philosophical views: the era of Antiquity, the Middle Ages, the New Age, the current state of the problem. This definition occupies a special place in modern philosophical and humanitarian discourse, in particular, in religious studies. Significant developments have expanded the etymological limits of «virtual reality» and turned this category into one of the central ones in modern philosophy. Based on the studies studied, it is possible to determine that virtual reality is a multidimensional, invariant, variable environment created with the help of computer technology, which has its own characteristics that can reorganize the existential world of a person. The objectified expression of a religious phenomenon in society is also experiencing a significant transformation under the influence of virtual reality.

Keywords: virtual reality, philosophy, virtualistics, ontology, space and time.

\author{
Скопа Виталий Александрович \\ Д.и.н., профессор, Алтайский государственный \\ педагогический университет, г. Барнаул \\ sverhtitan@rambler.ru
}

Аннотация: Рассматривается в исторической ретроспективе феномен виртуальной реальности через призму философских воззрений эпохи Античности, Средневековья, Нового времени, а также анализируется современное состояние проблемы. Данная дефиниция занимает особое место в современном философско-гуманитарном дискурсе, в частности, религиоведческом. Значительные наработки расширили этимологические пределы «виртуальной реальности» и превратили эту категорию в одну из центральных в современной философии. На основе изученных работ возможно определить, что виртуальная реальность - многомерная, инвариантная, переменная среда, созданная с помощью компьютерной техники, которая имеет свои характеристики, способные реорганизовать бытийный мир человека. Значительную трансформацию под влиянием виртуальной реальности испытывает и объективированное выражение религиозного феномена в обществе.

Ключевые слова: виртуальная реальность, философия, виртуалистика, онтология, пространство и время.

ряду с этим, следует отметить исследования в области виртуалистики российских ученых М. Эпштейна, А. Иванова, М. Кунафина $[8,10,15]$. В последние годы существенно возрос интерес к изучению данного феномена, что нашло отражение в научных статьях, монографиях и диссертационных работах и объясняется это во многом идущим процессом глобализации, быстрым изменением и трансформацией устоявшихся систем. Так, можно отметить исследования Ф. Власенко, А. Карина, А. Сотниковой. В целом, исходя из этого можно определить возрастающий научный интерес к данному феномену, а вместе с тем вычленить формирование множественных подходов к определению сущностного понимания виртуальной реальности.

Основной целью данной статьи является теоретический анализ подходов к пониманию феномена виртуальной реальности в философско-религиоведческом дискурсе.

В последней четверти XX-начале XXI вв. в различныX областях научного знания стали применять понятие «виртуальность», чтобы обозначить особые условия возникновения и функционирования определенных объектов, в частности, виртуальная коммуникация, виртуаль- 
ный музей, виртуальные частицы, Высшая Виртуальная магия. В этот же период появляется много научно-теоретических исследований, где понятие «виртуальность» становится если не центральным, то одним из таких. Уже в первых работах, посвященных онтологии виртуальной реальности, постулируется утверждение, что «гуманитарная теория не может отвергать идею виртуальной реальности» [11]. Именно поэтому возникает необходимость исследовать это понятие, корни которого восходят к периоду античности. Так, уже в трудах древнегреческих философов можно проследить кардинально противоположные подходы к истокам понимания данного понятия. Исследователи О. Немыкина, А. Карина находят идею виртуальности в трудах Платона и Аристотеля. В частности, О. Немикина утверждает, что идея виртуальности раскрывается в философских трудах Аристотеля в таких категориях как «dynamis» (возможность, потенция), «energeiа» (энергия, деятельность), «entelecheia» (осуществимость) [12]. Важно заметить, что речь идет именно о единичной интерпретации идеи виртуальности в древнегреческой философии, а не о самом понятии, ведь как таковое оно отсутствовало в трудах мыслителей этой эпохи. Исследователь П. Богачевский убежден, что первые интерпретации понятия «виртуальной реальности» следует искать в трудах римского оратора Цицерона и схоластической философии [2]. Он, как и большинство ученых обращаются к фундаментальным исследованиям Н. Носова, который, в свою очередь, апеллирует к трудам Цицерона и средневековым схоластам [3, 13]. Исследователь считает, что древнегреческая философия не может найти механизм энергетической связи всеобщей абсолютной сущности с активностью единичных предметов потому что это выходит за пределы предметного поля исследования философов этого времени [3, с. 74]. В тоже время в трудах римского оратора Цицерона понятие «virtus» употребляется для обозначения качеств характера воинов, таких как доблесть, мужество, добродетель. Такое понимание понятия «virtus» противоречит всем последующим трактовкам. Продолжая, Н. Носов сводит это к проблеме перевода и отсутствия надлежащих комментариев для понимание древних текстов [3, с. 124].

Для средневекового человека является определяющим существование определенной силы (virtus), что переводит объект из состояния небытия в состояние бытия [6]. Только в схоластической философии для обозначения актуальной действующей силы использовали понятие «virtus», то есть «объект получает возможность действия» [3, с. 70]. Его применили для решения определенных схоластических проблем, а именно «формирование сложных явлений из простых, соотношение потенциального и актуального, как энергетическую составляющую акта действия» [7, с. 184]. Например, католический теолог Фома Аквинский через категорию «виртуальности» объяснял конституирование разумной (мыслящей) души, содержащей в себе виртуально веге- тативную душу и душу сенситивную [1].

Гипотезу о том, что определенная реальность может производить другую реальность выдвинул еще в IV в. один из Отцов Церкви - Василий Великий. Он утверждал: «Ум есть паттерн, получаемый умом. Это довольно тавтологично, но не порочно и не парадоксально» [7, с. 183].

В работах еще одного средневекового философа Н. Кузанского можно выделить иную трактовку понятия «виртуального». В работе «О видении Бога» категория «virtus» используется для объяснения дуальности - потенциального и актуального, когда при определенных условиях потенция реализуется в действительность [9]. Для объяснения этого процесса философ использует метафору с ореховым деревом. Актуальное состояние хорошего дерева с пышной кроной человек способен созерцать «телесными глазами». В случае, если мы хотим увидеть, что лежит в основе развития этого дерева, тогда согласно концепции ученого, мы переходим на высокий уровень мироздания. На этом уровне каждая частица дерева виртуально содержит в себе конкретно-эмпирическое дерево, а также и все конкретно-эмпирические деревья. Третьим и самым высоким уровнем мироздания, согласно учению философа, будет основа первооснов Бог, наполняет семена потенциальной силой развиться и прорасти. Бог рассматривается как абсолютная сила всех сил, где семантика потенциальности в совокупности с виртуальностью приобретает новый вид - первооснову $[1,6]$. Таким образом, философ, чтобы объяснить некоторые явления, использует традиционную для средневековой схоластики методологию - рассматривает явление не с позиции их внутренней структуры, а через высшие силы, и применяет для этого категорию «virtus».

В эпоху Нового времени происходит становление монистической парадигмы, где постулировалась идея одной реальности - природной, а понятие «virtus» употребляется для обозначения всепроникающей силы, которая способна влиять на акт действия. Дальнейшее развитие науки позволяет проследить это в различных видах монизма (идеализм, физикализм, нейтральный монизм) [12].

Сформированный базис научного познания позволяет выделить более основательные теоретические исследования на тему виртуальной реальности, которые начали появляться в рамках постнеклассической философии в последней четверти XX в. Такие известные философы как Ж. Бодрийяр, Э. Кастельс, М. Маклюэн, М. Постер ставят вопросы о гиперреальности, статусе индивида в виртуальной реальности, формировании новой культурной идентичности и предпринимают попытки вообще оценивать потенциал виртуальной реальности $[2,10]$.

Значительные наработки расширили этимологиче- 
ские пределы «виртуальной реальности» и превратили эту категорию в одну из центральных в современной философии. Несмотря на достаточно проработанную теорию виртуалистики, на современном этапе научного развития человечество еще четко не определилось в трактовке «виртуальная реальность». На основе рассмотренных исследований, возможно предложить узкое определение: виртуальная реальность представляется как многомерная, инвариантная, переменная среда, созданная с помощью компьютерной техники, которая имеет свои характеристики, способные реорганизовать бытийный мир человека.

В современных словарных и энциклопедических определениях, в основном, отождествляют виртуальную реальность с компьютерными технологиями, интернетом, что не соответствует этимологическим корням, но в тоже время соответствует современной специфике данного понятия [11].

«Виртуальная реальность» как «мысленный мир» существует с началом творческой деятельности человека, его культов, ритуалов, религии, науки, то есть, мира культуры. Таким образом мы видим широкое и узкое понимание «виртуальной реальности». Современная виртуальная реальность воспринимается в широком смысле, но развитие технологий способствует корректировке данного понятия, а вместе с тем и его сущности. Для данного исследования актуально именно узкое понятие «виртуальной реальности», то есть то понятие, которое связано с компьютерными технологиями, которые влияют на все сферы жизни человека и задают новый вектор развития общества [8]. Однако, важно понимать, что «внутренняя виртуальная реальность» человека порождена технологиями виртуальной реальности в чем они имитируют друг друга, ведь имеют сходство по своему смыслу и логике. Так, в работе Л. Кондратенко отмечено «главное различие в понимании сущности виртуального мира коренится в нежелании увидеть принципиальное единство/противоположность явлений «внутренней виртуальной реальности», которая всегда была порождающей основой творчества и современной компьютерной «виртуальной реальности», которая является попыткой переноса внутренней реальности наружу» [16].

Однако отличие новой виртуальной действительности заключается в ее технической специфике, которая обеспечивает неограниченную вседоступность для любого человека, потому что выходит за пределы индивидуального и превращается в глобальную среду. Если рассматривать более широкое определение (виртуальная реальность как мир культуры, духовного творчества человека), тогда это явление будет иметь более индивидуальный характер, поскольку мы не можем проникнуть в «виртуальность» человека, который что-то создал, следовательно, его виртуальность для нас недоступна, она не эксплицируется полностью. Тогда как компьютерная виртуальная реальность делает ставку на трансляцию, экспликацию. В ней важно лишь то, что показано извне, она вся во внешней среде.

В пространстве глобальных медиаторов особое мнение или отдельные изобретения теряются. Для человека будущего, который будет вынужден адаптироваться к вызовам времени, поскольку выступать в роли связного между элементами различных систем, важным будет сохранить свои духовные основы, чтобы не потеряться в бездорожье виртуальной реальности [12]. Виртуальная реальность, как компьютерный интерфейс, требует, чтобы человек использовал свои физические свойства, зрение, слух, а еще чувственное восприятие, что необходимо в процессе обработки звуковой информации. Весьма интересным является рассуждение М. Эпштейна, который отмечал, что «с увеличением реальностей и миров, могут приобрести особое влияние «негативные религии», призванные, освободить человека от страданий и путешествий по нелепой бесконечности миров» [15].

Несмотря на предостережения ученых, Интернет сегодня незаменимый ресурс, коммуникационное пространство, источник развития популярных культурно-социальных тенденций, место зарождения новых религий. В одной из последних статей итальянского философа У. Эко отчетливо прослеживается утверждение, что «прогресс сети остановить невозможно», поэтому нужно научиться правильно использовать ресурс, который способен принести большую пользу человечеству [14].

Значительную трансформацию под влиянием виртуальной реальности испытывает и объективированное выражение религиозного феномена в обществе, а именно религиозность. В смысловых ориентирах верующего человека религиозность играет чрезвычайно важную роль - влияет на его мировоззренческо-ценностные ориентиры [10].

Новая социокультурная реальность обусловливает новые формы функционирования религиозности. Поэтому, дифференцируя феномен религиозности, ученые выделяют такое понятие, как «современная религиозность, обусловленная наличием и проявлениями виртуального отношения современного человека к сверхъестественному: Богу, Высшей силы, Космическому разуму» [6, с. 204]. Современная религиозность заключается в том, что она стремится осмыслить и интерпретировать события современной общественной жизни, достижения в сфере науки и техники, технологий, исходя из явлений и процессов действительности. Так, в понимании В. Еленского, «постмодерн религиозности означает конструирование и реконструкцию внецерковных «диффузных» проявлений религии, где причудливо сочетаются наборы ценностей, символов, обычаев и поведенческих норм» [7, 
с. 312]. Таким образом можно отметить, что религиозность является динамичной составляющей, поэтому может изменяться в соответствии с индивидуальными особенностями человека и общей культурно-общественной парадигмой. Исследование проявлений постмодернистской религиозности было бы не полным, если не учитывать процессы виртуализации, которые своей глобальностью влияют на индивида, а затем приводят к трансформации форм религиозности последнего.

Адаптировавшись в виртуальной реальности, лицо использует ее во многих своих потребностях, в частности в необходимости религиозного опыта. Например, с помощью Интернет человек реализует свои молитвенные нужды. Это происходит либо через обычное чтение молитвы с экрана своего гаджета, или же из-за записи просьбы о молитве Господа на специально созданном для этого сайте. На религиозных или светских форумах человек может четко выражать свои вероисповедальные принципы [6].

В виртуальном пространстве можно найти множество публикаций, посвященных религиозной деятельности. Это могут быть различные научно-исследовательские статьи, новости о жизни той или иной религиозной организации. Кроме того, на веб-сайтах размещено мно- жество библиотек с большим количеством богословских и академических текстов на религиозную тематику, которые открыты для чтения. Учитывая высокий уровень виртуализации современной культуры новые коммуникационные возможности стали доступны благодаря функционированию Интернет, их начали использовать многочисленные религиозные организации для сохранения и развития своих верований.

Итак, если подвести итог, то можно отметить, что явление виртуальной реальности - «ребенок постмодерна». Проблемы, связанные с виртуальной реальностью, стали чрезвычайно актуальными в современном обществе. Процессами информатизации и виртуализации пропитаны все сферы жизни человека, начиная от науки, культуры, технологий и сейчас находят свое продолжение в религиозной сфере. Понятие «виртуальный» в философском дискурсе появляется еще во времена античности. Современные исследования в основном направлены на осмысление онтологии виртуальной реальности и сопоставление двух реальностей - субстанционной и виртуальной. Необратимость процессов виртуализации побуждают к дальнейшим детальным исследованиям в этой сфере, чтобы использовать потенциал виртуальной реальности на благо человечества.

\section{ЛИТЕРАТУРА}

1. Аквинский Ф. Сумма теологи // Антология мировой философии. М., 1969. Т. ІІ. Ч. 2. С. 810-823.

2. Богачевский П.С. Концепт виртуальности в предметном поле современной философии науки // Вестник Житомирского государственного университета. 2012. Вып. 65. Философские науки. С. 19-24.

3. Виртуальная реальность: Философские и психологические проблемы / под ред. док. психолог. наук Н.А. Носова. М., 1997. 183 с.

4. Готт В.С. О философских вопросах теории виртуальных частиц и процессов // Философские науки. 1965. № 4. С. 10-20.

5. Грязнова Е.В. Виртуальная реальность: анализ смысловых элементов понятия // Философские науки. 2005. № 2. С. 125-143.

6. Докаш В., Моргоч И. Религия как фактор идентификации личности: социокультурный аспект // Религия и социум. 2014. № 1-2. С. 199-208.

7. Еленский В. Великое возвращение: религия в глобальной политике и международных отношениях конца XX - начала XXI века. Льв0в, 2013. 504 c.

8. Иванов А.Е. Виртуальная реальность // История философии. Энциклопедия. Минск, 2002. С. 183-186.

9. Кузанский Н.0 видении Бога [Пер. В.В. Бибихин] // Сочинения в 2-х т. М., 1998. Т. 2. С. 40-50.

10. Кунафин М.С. Виртуальное бытие // XXI век: будущее России в философском измерении : матер. II Российского философского конгресса. Т. 1, Ч. 2. Онтология, гносеология и методология науки, логика. Екатеринбург, 1999. С. 73-74.

11. Микешина Л.А. Новые образы познания и реальности. М., 1997. 240 с.

12. Немыкина 0.И. Понятие виртуальности в философском контексте // Известия высших учебных заведений. Поволжский регион. Гуманитарные науки. 2011. № 1 (17). С. 53-62.

13. Носов Н.А. Словарь виртуальных терминов // Труды лаборатории виртуалистики. Вып. 7. М., 2000. 69 с.

14. Эко У. Прогресс сети остановить нельзя // Частный Корреспондент [Электронный ресурс]. - Режим доступа к ресурсу: http://www.chaskor.ru/article/ umberto_eko_progress_seti_ostanovit_nelzya_36583.

15. Эпштейн М. Протеизм. Манифест начала века [Электронный ресурс]. - Режим доступа к ресурсу: http://www.topos.ru/veer/07/v7_proteism1.html.

16. Кондратенко Л.А. Влияние информационно-компьютерных технологий на когнитивное развитие детей (между двумя реальность) // Технологии развития интеллекта. № 4. 2013. С. 173-193.

(с) Скопа Виталий Александрович (sverhtitan@rambler.ru). 